www.jmscr.igmpublication.org

Index Copernicus Value: 79.54

ISSN (e)-2347-176x ISSN (p) 2455-0450

crossref DOI: https://dx.doi.org/10.18535/jmscr/v7i4.178

\title{
Audit of Histopathology Request Forms Submitted in Laboratory of a Tertiary Care Hospital
}

\author{
Authors \\ Dr Priyadharisini ${ }^{1 \star}$, Dr Sivaganesh Porko ${ }^{2}$, Dr Partho Protim Barman ${ }^{3}$ \\ ${ }^{1,2}$ Assistant Professor, Department of Pathology, Sri Lakshmi Narayana Institute of Medical Sciences, \\ Puducherry, India \\ ${ }^{3}$ Professor, Department of Pathology, Sri Lakshmi Narayana Institute of Medical Sciences, Puducherry, \\ India \\ *Corresponding Author \\ Dr Priyadharisini \\ Mobile no: +919790095099. Email: priyadharsini158@gmail.com
}

\begin{abstract}
Background: The quality of the laboratory result lies in the quality of information provided in the laboratory request forms. Majority of laboratory errors arise from the preanalytical phase of sample testing and hence this study was conducted.

Aims: This study aims to assess the level of completion of histopathology request forms submitted for investigations in our institute.

Methods and Material: A review of all histopathology request forms received between January to December 2018 were evaluated to assess the level of performance in four domains of data in the request forms such as patient details, test request details, physician details, and specimen details. Descriptive statistical analysis was done

Results: In our study, only $12.2 \%$ of forms evaluated were fully completed. Patient identification details, the signature of requesting physician and request date were the most completed information (100\%) and least completed information been timeline category for reporting $(8.7 \%)$.

Conclusions: This study shows that patient clinical information and physician details were inadequately filled in our setting. There is a need to create awareness of the importance of appropriate filling of request forms among in house surgeons and referring physician and also encourage them to use self-inking stamps for physician identification. Regarding clinical data, the histopathology request forms may be reviewed and redesigned to allow physicians to fill the forms without omitting significant history.
\end{abstract}

Keywords: Laboratory request forms, histopathology, preanalytic errors, data analysis.

\section{Introduction}

The current era of evidence-based medicine is increasingly dependent on reliable laboratory services. Errors in laboratory reports are generally classified into pre-analytic, analytic and postanalytic phase of sample testing of which majority
(50-70\%) arise due to preanalytic errors (which are not under control of laboratory personnel) such as specimen transportation and delivery (mislabelling of container and wrong fixative) and absence of important clinical information in laboratory request forms, which can have serious effect on patient 


\section{JMSCR Vol||07||Issue||04||Page 1085-1089||April}

care $^{1,2,3}$. Laboratory request forms are the first line of communication between clinician and pathologists which provides patients with relevant clinical details and information regarding the test to be performed. The quality/accuracy of the test result is dependent on the quality of information providedin the request forms, thereby helps mutual best practice for each other

This study aims to assess the level of completion of histopathology request forms submitted for investigations in our institute so as to find the degree of deficiencies in data provided by requesting physicians and also to emphasise the importance of appropriate filling of request forms in future.

\section{Materials and Methods}

This was a retrospective descriptive study. Histopathology Request forms for investigations received in our central laboratory between January and December 2018 were retrospectively evaluated to measure the compliance of referring clinicians in adequate completion of request forms. Each request form was assessed for the presence and completeness of the information requested therein: patient details; (identity-full name, age, gender, OP/IP number; clinical information- nature and duration of symptoms, site of lesion, relevant investigations including imaging, provisional clinical and differential diagnosis; type of surgery); test request details- Request date, Timeline category for reporting; physician details (name and signature of the requesting clinician, clinical unit); Specimen details- Date and time of collection of specimen. These data should be present on $100 \%$ of requests if completed correctly.

\section{Results}

A total of 114 histopathology request forms received during the study period and all were evaluated for patients details, test request details, physician details as well as specimen details. Out of 114 forms evaluated, only $12.2 \%$ of forms were fully completed and $100(87.8 \%)$ had one or more information missing. The results were analyzed and tabulated accordingly.

The rate of completion of data elements on the request forms are as follows; Table- 1,2,3,4

Patients name, OP/IP number, the signature of referring clinician, date of the request were the most completed information $(100 \%)$ in all the forms. Name of the referring clinician(38.5\%), nature and duration of symptoms(35\%), relevant investigation reports(30.7\%), time of sample collection(24.5\%) and timeline category for reporting $(8.7 \%)$ were the least provided information (less than 50\%) in the decreasing order of frequency.

Table 1 Rate of completion of patients details

\begin{tabular}{|l|c|c|}
\hline Patients details & $\begin{array}{c}\text { Number of cases } \\
\text { (out of 114) }\end{array}$ & $\begin{array}{c}\text { Frequency of } \\
\text { cases (\%) }\end{array}$ \\
\hline Name & 114 & 100 \\
\hline Age & 112 & 98.3 \\
\hline Sex & 112 & 98.3 \\
\hline OP/IP number & 114 & 100 \\
\hline Patients clinical information & 35 \\
\hline $\begin{array}{l}\text { Nature and duration } \\
\text { of symptoms }\end{array}$ & 40 & 77 \\
\hline Site of lesion & 88 & 30.7 \\
\hline $\begin{array}{l}\text { Relevant } \\
\text { investigation } \\
\text { including imaging }\end{array}$ & 35 & 94.7 \\
\hline $\begin{array}{l}\text { Provisional/ } \\
\text { differential } \\
\text { diagnosis }\end{array}$ & 108 & \\
\hline Type of surgery & 102 & 89.4 \\
\hline
\end{tabular}

Table 2 Rate of completion of physician details

\begin{tabular}{|l|c|c|}
\hline Physician details \\
\hline Name & 44 & 38.5 \\
\hline Signature & 114 & 100 \\
\hline Clinical unit & 97 & 85 \\
\hline
\end{tabular}

Table 3 Rate of completion of specimen details

\begin{tabular}{|l|c|c|}
\hline Specimen details & $\begin{array}{c}\text { Number of } \\
\text { cases }(/ 114)\end{array}$ & $\begin{array}{c}\text { Frequency of } \\
\text { cases }(\%)\end{array}$ \\
\hline Date of collection & 114 & 100 \\
\hline Time of collection & 28 & 24.5 \\
\hline $\begin{array}{l}\text { Specimen received in } \\
\text { formalin fixative }\end{array}$ & 102 & 89.8 \\
\hline $\begin{array}{l}\text { Specimen received in } \\
\text { appropriate container }\end{array}$ & 97 & 85 \\
\hline
\end{tabular}

Table 4 Rate of completion of test request details

\begin{tabular}{|l|c|c|}
\hline Test request details & $\begin{array}{c}\text { Number of cases } \\
(/ 114)\end{array}$ & $\begin{array}{c}\text { Frequency of } \\
\text { cases }(\%)\end{array}$ \\
\hline Requesting date & 114 & 100 \\
\hline $\begin{array}{l}\text { Timeline category } \\
\text { for reporting }\end{array}$ & 10 & 8.7 \\
\hline
\end{tabular}




\section{Discussion}

'Microscopic diagnosis is a subjective evaluation that acquires full meaning only when the pathologist is fully cognizant of the essential clinical data, surgical findings, and type of surgery' as stated by Juan Rosai ${ }^{4}$. The importance of appropriate filling of request forms is usually underestimated by the clinicians. Inadequate information or errors while filling out laboratory request forms can significantly impact the quality of laboratory results and, ultimately, patient outcomes. This study was an attempt to assess the level of completion of request forms by the referring clinicians, so as to put forth some deficiency correction management in near future. The significance of proper filling of laboratory request form is regularly emphasized at orientation programs for in house surgeons. It is the duty and discipline of the requesting surgeon to make sure that both the specimen container and the request forms are correctly and adequately completed.

\section{Specimen Details}

Date and time of specimen collection allow adequate appropriate time for tissue fixation and helps to plan a schedule for tissue processing. Immediate fixation of the surgical specimen will reduce the warm ischemia time which has an effect on test outcome. Unfixed specimens are unsuitable for special studies and no definitive microscopic diagnosis possible further. Inappropriate specimen containers may distort the specimen morphology and may prevent pathologist to obtain gross clues from it.

\section{Patients Details}

Patients demographic details helps to identify correct patients and allow cross-referencing of previous reports if available. Patients adequate clinical information allows relevant use of special stain, therefore, directs pathologist's to render a definite diagnosis. Inadequate clinical information was defined as the pathologists need for additional clinical information before a diagnosis is rendered, regardless of the amount of information already present on the request forms.

Provisional clinical diagnosis/ differential diagnosis is not to bias the pathologists' mind rather know the surgeon mind and answer their questions regarding patients presentation. Information regarding the type of surgery allows the pathologist to choose an appropriate technique of grossing the specimen.

\section{Test Request Details}

Knowledge of the test required directs the sample to the concerned laboratory department. Requesting date doesn't have any clinical significance rather it acts as a check for Turn-around Time for reports which is a quality indicator. Timeline category for reporting allows prioritization of sample processing.

\section{Physician Details}

Details of requesting clinical unit and the physician details such as name and contact number will allow getting additional information easily and also to convey any urgent results.

Various studies from different regions have been reported to show deficiencies in filling up the request forms for various investigations $5,6,7,8$. Despite numerous data elements on the request forms, clinical data were the most discussed in many studies. There are only limited studies available in regard to completion of histopathology request forms in the recent period, kindled us to do an analysis of the level of completion of histopathology request forms submitted in our laboratory.

In our study, only $12.2 \%$ of forms were fully completed which is higher than similar studies done by Olufemi et al, Jegede $\mathrm{F}$ et al with $1.3 \%, 9.4 \%$ respectively and Makubi et al showing 100\% lack of fully completed information ${ }^{9,10,11}$. This wide variation in the results of various studies could be due to deficiency/ implementation of strict hospital/ laboratory policies. The pulse of any laboratory request forms lie on the clinical information data which was completed in $94.7 \%$ of forms in our study, which was corroborated well with similar studies done by Burton et al., Nakhleb and Zarbo et 
al., Kansay $\mathrm{S}$ et al with $93.9 \%, 97.6 \%, 96.8 \%$ respectively ${ }^{12,13,14}$.

The other data parameters on request forms were analyzed as well and found concordant with previous similar studies done by Makubi et al and Adegoke et al. ${ }^{11,15}$. [Table 5]

Table 5 Comparison of rate of completion of various parameters in the request forms

\begin{tabular}{|l|c|c|c|}
\hline & Our study(\%) & $\begin{array}{c}\text { Makubi et } \\
\mathrm{al}(\%)^{11}\end{array}$ & $\begin{array}{c}\text { Adegoke et } \\
\mathrm{al}(\%)^{15}\end{array}$ \\
\hline Patient name & 100 & 100 & - \\
\hline Age & 98.3 & 93 & 87 \\
\hline Sex & 98.3 & 93 & 87 \\
\hline $\begin{array}{l}\text { OP/IP } \\
\text { number }\end{array}$ & 100 & 97 & 95.4 \\
\hline $\begin{array}{l}\text { Physician } \\
\text { name }\end{array}$ & 38.5 & - & - \\
\hline Signature & 100 & 92.3 & 96 \\
\hline
\end{tabular}

In our study, $10.2 \%$ of specimens were received in normal saline instead of formalin and $15 \%$ of the specimen were received in the inappropriately sized container. These results were corroborated with a similar study done by Akinfenwa et al with $20 \%$ specimens received with no fixative and $16.5 \%$ samples received in the inappropriate container ${ }^{16}$.

\section{Conclusion}

This study shows that patient clinical information and physician details were inadequately filled in our setting. Inadequately filled request forms may cause redundancy in laboratory services and may cause a delay in diagnosis while trying to retrieve such omitted information. There is a need to create awareness of the importance of appropriate legible filling of request forms among in-house surgeons and referring physician as well as to ensure prompt fixation of specimen and transportation. They can be encouraged to use self-inking stamps for physician identification. Regarding clinical data, the histopathology request forms may be reviewed and redesigned to allow physicians to fill the forms without omitting significant history.

\section{Key Message}

Inadequate filling of histopathology request forms can limit the advice of pathologists when interpreting the results, hence regular audit on completeness of histopathology request forms by every laboratory acts as a quality check and also helps providing feedback loop for requesting physician which can be communicated them during interdepartmental meeting.

\section{References}

1. Plebani M, Sciacovelli L, Aita A, et al. Harmonization of pre-analytical quality indicators. Biochemia Medica. 2014;24 (1):105-113.

2. Sirota RL. Error and error reduction in pathology. Arch Pathol Lab Med 2005;129:1228-33.Google Scholar

3. Laposata M, Dighe A. "Pre-pre" and "postpost"analytical error: high-incidence patient safety hazards involving the clinical laboratory. ClinChem

$\mathrm{Lab}$

Med. 2007;45(6):712-719. [PubMed]

4. Rosai J. Introduction. In: Rosai J, ed. Ackerman's Surgical Pathology. St Louis, Mo: Mosby; 2005:1-19.

5. Nutt L, Zemlin AE, Erasmus RT. Incomplete laboratory request forms: the extent and impact on critical results at a tertiary hospital in South Africa. Ann ClinBiochem. 2008;45(5):463-

466. [PubMed]

6. Zemlin AE, Nutt L, Burgess CJ, Eiman F, Erasmus RT. Potential for medical error: incorrectly completed request forms for thyroid function tests limit pathologist's advice to clinicians. South African Medical Journal. 2009;99(9):668-671. [PubMed]

7. Olayemi E, Asiamah-Broni R. Evaluation of request forms submitted to the haematology laboratory in a Ghanaian tertiary hospital. The Pan African Medical Journal 2011;8(33) [PMC free article] [PubMed]

8. Afolabi OA, Fadare JO, Essien EM. Audit of completion of radiology request form in a Nigerian specialist hospital. Ann Ib Postgrad 
Med. 2012 Dec;10(2):48-52. [PMC free article] [PubMed]

9. Olufemi Abiola Oyedeji, ${ }^{1, \&}$ Abiola Ann Ogbenna, ${ }^{1}$ and Sandra Omozehio Iwuala ${ }^{2}$. An audit of request forms submitted in a multidisciplinary diagnostic center in Lagos Pan Afr Med J. 2015; 20: 423

10. Jegede F, Mbah HA, Dakata A, et al. Evaluating laboratory request forms submitted to haematology and blood transfusion departments at a hospital in Northwest Nigeria. Afr J Lab Med. 2016;5(1), a381

11. Makubi AN, Meda C, Magesa A, Minja P, Mlalasi J, Salum Z, et al. Audit of clinical- laboratory practices in haematology and blood transfusion at Muhimbili National Hospital in Tanzania. Tanzan J Health Res 2012;14:257- 62.

12. J L Burton, T J Stephenson. Are clinicians failing to supply adequate information when requesting a histopathological investigation? J Clin Pathol2001;54:806-808

13. Nakhleh RE, Zarbo RJ. Surgical pathology specimen identification and accessioning: a College of American Pathologists Q-Probes study of $1004 \quad 115$ cases form 417 institutions. Arch Pathol Lab Med 1996;120:227-33.

14. Kansay S, Verma M. Evaluation of request forms received in blood bank and biochemistry laboratory in a teaching hospital in North India: A comparative study of preanalytical errors. J Nat Accred Board Hosp Healthcare Providers 2016;3:20-6.

15. Adegoke OA, Idowu AA, Jeje OA. Incomplete laboratory request form as a contributory factor to preanalytical errors in a Nigerian teaching hospital. Afr J Biochem Res 2011;5:82- 5.

16. Akinfenwa T Atanda and Solomon Raphael ${ }^{1}$ Role of Surgeons in Determining Outcome of Histopathology Specimens, Niger J Surg. 2013 Jul-Dec; 19(2): 68-72. 